\title{
計算機画像処理と絨維工業への応用
}

1. まえがき

宇宙探查のためのりモートセンシングの要求から研究 開発されたディジタル画像好理は，とれを支えるハート ウェアの集皘化技衙の進歩により，通信，医用などの各 分野に利用されてきた。

織維工業の分野で，画像好理の技術は，画像の特質で ある面的な広がりを生かすととができる「2次又は 3 次 の織維製品の設計，製造，検查の部門」に応用できる。 画像炕理技術を応用したシステムで実用化されている あのK(i) 織物の柄出しシステムム,2) (ii)維製に用いら れるサンプルパターンの設計システム゙）（iii）織布の久 点の検出システム゙などがある。

（门は，回転ドラムに巻きつけられた図案を光電変換 器で読み取って，色の信号処理をし，敉紙を穿孔するす のである。

(ii)は、ファッションのデザィンに㕲りる図形の作成、 変換を行うあので、デザイナを援助するシステムである。

(iii)は、パターン㑇識にすとつく画像処理技術により， 系の結び目，穴，污れ，染色むらなどの欠点を検討する システムである。画像好理の立場からみて，(iil)に関す るものは，識別，分類などに高度の姏理を必要とするの で、今後，研究の対象になるもの之思われる。

マイクロプロセッサの高性能化，半導体メモリの高速 大容量化，半導体の撮像装置の高性能化が進めば，画像 処理のハードウェアは容易に入手できるようになるので， 画像処理技街は織維工業の各部門に導入されるもの上考 えられる。

そこで，ここでは，画像処理の基礎的な事項について

Computer Image Processing and its Application to the Textile Industry

KEIJI TANIGUCHI ${ }^{* 1}$, HIDEO OGAWA*2

Dept. of the Electronics Engineering, Faculty of Engineering, Fukui University.

Bunkyo, Fukui-City, Japan.

福井大学工学部電子工学科 教授 (工博)*1

福井大学工学部電子工学科 助教授 (工博 $)^{* 2}$
谷口零治*1・小川秀夫"2

概説し，画像姏理に上る染色欠点検出への一武みを紹介 する。

2. 画像処理システムのハードウェア

この部分は，対象物を電気信号に变換する撮像部，丁 ナログディジタル変換部(A-D Converter)，画像メモ リ）情報処理部などから構成され，図1にその例を示す。

(i) 提像部

対象物加らの透過光又は反射光を電気信号比変换する 部分である。その方法は，図2のように，光を赤(Red)， 緑 (Green)，青(Blue)のフィルタを通して3原色仿分 光し，これをそれぞれ 3 個の光電变換器に導く。 光電変換器には，(a)炕電子增倍管，(b)撮像管，(c)

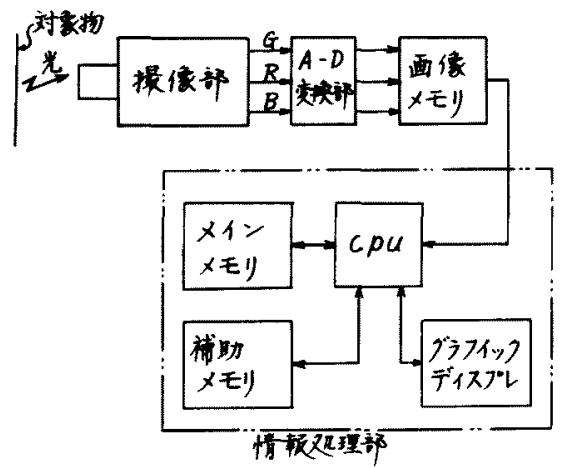

因1 画像知理システムのハードウェアの 構成の一例

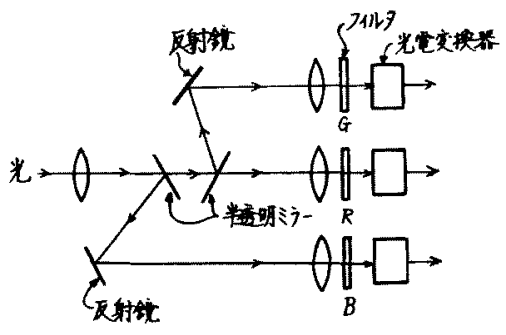

図 2 撮像部の光学少の構成 
半導体イメージセンサが用いられる。

（a）は，高感度であるが，走査回路を持たないので， 文献1)のような方法などにより，対象物を走査するこ 上が必要である。

（b）は，現在、テレビカメラに使用されているが，寿 命が 2000 時間程度であり，特性の経日変化が生じるな どの欠点がある。

（c）は，(b)飞比べて，特性の変化加位とんどなく， 蛢付が起てらないなど多くの利点をもっているので，画 像処理にはよく用いられる。これには，MOS形とCCD 形があり，素子の配列から一次元と二次元のものがある。 一次元MOS形イメージセンサの例を図 3 に示す。

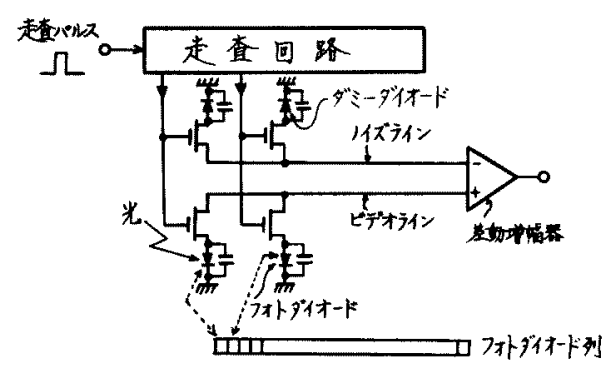

図 3 一次元半導体イメージセンサの例

\section{(ii) $\mathrm{A}-\mathrm{D}$ 桨換部}

撮像部からのアナログの画像信号をディジタル量に変 換する部分で，ここでは，図4のように，標本化と量子 化加行われ吕 ${ }^{21)}$ 。

\section{標本化}

図 4(b)Oように，アナログ信号 $v(t)$ (図 4(a)) 䘮時 間軸方向に対して不連続(離散)化する操作である。画像 の性質を保存するためには，標本化時間 $T$ を次の上うに 選ふととが必要である゙。

$$
T \leqq \frac{1}{2 f_{\max }}
$$

ここで， $f_{\max }$ は画像信号に含まれている最大周波数成分 である。

以上は，一次元の場合の説明であるが，二次元につい ては文献 9)を参照されたい。

量子化

標本化されたアナログ信号を $v(k T)$ とするとき，

$$
\begin{aligned}
& n V_{d}-\frac{V_{d}}{2} \leqq v(k T)<n V_{d}+\frac{V_{d}}{2} \\
& n=0,1,2, \cdots, m
\end{aligned}
$$

を満足する $v(k T)$ に刘 L

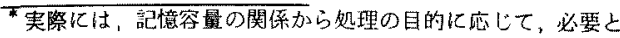
する情報汃含まれるように選ふ。
}

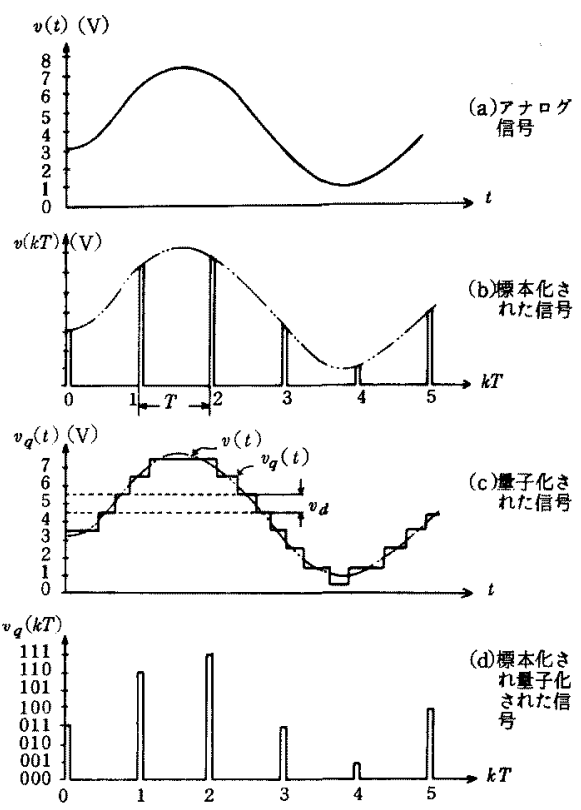

図 4 標本化上量子化

$$
v_{q}(k T)=n V_{d}
$$

のように不連続な值 $v_{q}(k T)$ に変換する操作である(図 4 (c))。

例えば， $f_{\text {max }}=1 \mathrm{MHz}$ で $0 \leqq v(t)<2.55(\mathrm{~V})$ のとき， $V_{d}=0.01(\mathrm{~V})$ に量子化する場合のA-D变換器の精度 $B$ (ビット)之変換時間 $t_{c}$ は次のようになる。

$$
\begin{aligned}
& 2^{B}-1=\frac{2.55}{0.01} \text { 上り } B=8(\text { ビット) } \\
& t \leqq T=\frac{1}{2 \times 10^{-6}}=0.5(\mu \mathrm{s})
\end{aligned}
$$

図 4(d)は，゙ィジタル化された信号の例である。

(iii) 画像メモリ

A-D変換された画像情報を記憶するためのもので， 標本化時間 $T$ よりやや短いアクセスタイムのメモリを用 いる。

\section{(IV) 情報処理部}

CPU，メインメモリ，補助メモリ，グラフックディ スプレーなどから構成される。

\section{3. 画像処理技術}

画像処理技術とは，先に示したハードウェアシステム の機能を能率よく，十分に，発揮させるためのソフトウ エア，及び画像の生成，解析あるいは，認識(理解)を行 うための種々の技法をいう。

ソフトウェアとしては，画像が本来面的広がりを持ち 


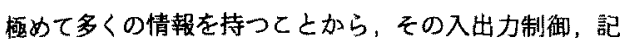
憶画像データの管理など，特有の機能が必要之なる。さ らに，処理方式として，入力画像データや処理の中間結 果を逐次把㩧し，それに基づいて，次の処理を指示する 対話(会話)形式の処理か実際的であり，てれを可能とす るソフトゥェアあ重要である。現在、ソフトゥェアの機 能，あるいは形態は，ハードウェアシステムと合わせて， 多(の咞究開発加進められ，例えば，文献 4)，5，6)な どに詳しい解説がある。

画像処理技法は，その目的により，(i 画像の生成上 変換，(ii) 画像の分割之特徽抽出 (記述), (iii) 画像の認 耖(理解)などに分類されるが，とてでは，前 2 者を中心 飞概説する。

\section{(i) 画像の生成と裂換}

画像の生成には，㵊度，色，形，位置関係などをパラ メータとして種っの図形を発生させ，人間により評価を 行うグラフィックデザィンあるいは，近年の計算機了 ーメーション，また多方向からの投影像を基伅，断層像 を合成する計算機トモグラフィー(CT)の技術”がある。

画像の変換には，应大，回転，非線形座標変換などの 幾何学的处理があり、コマンドとパラメータを与えるて とにより，会話的に処理を進める計算機援用設計 (CAD)

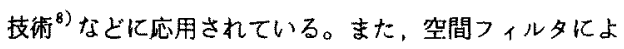
る画像の雑音除去，ボケの回復などの画像復元技術，あ るいは空間周波数帯域制限, 空間微行演算などによる画 像の強調処理技術あ画像の変換とみることができる゙，10）

表1K，微分オペレータの一例之，それを用いた処理 例を示す。微分处理では，濃度变化の大きなところ，即 ち、線，領域の境界(エッジ)などを強調，あるいは検出 することができる。

また，謷度值に対して，適当な色を割り当る擬似力ラ 一表示屯画像の强調技術であり，種々のデザインの分野
で応用できよう。

画像の生成，変換技術は人間住対して，見やすい画像 を提供し，判断の助けとすること，及び次に述へる面像 の分割，特徽抽出を容易にするための前处理的役割加， 主な目的である。

\section{(ii))画像の分割と特晸抽出(記述)}

画像を共通の属性を持つ領域に分割し，個々の領域内 をさらに詳しく調へ，その形状，あるいは領域間の関保 を見い出したい場合が多い。領域分割を行うための情報 としては，濃度，色，テクスチャーなどが代表的である。 例えば，濃度ヒストグラムを調へることにより，それ が双峰形であれば，二つの領域が推定でき，ヒストグラ ムの谷に対応する濃度を闘値として，領域を分割するこ とができる。色柇画像では，3原色の分布あるいは色度 の分布を調へ，それがクラスターを形成すれは，個々の クラスターに画像の領域を対応させることができる゙”。

次に、テクスチャ一解析の代表的な手法 ${ }^{22}$ として、二 次元フーリェ変換化上り画像の空間周波数を求め，その パワースペクトルの類似性を見るもの，画像上で相対的 亿同一位置にある 2 点の漂度值の共発生行列加ら種々の 統計星を得るものがある。テクスチャ一解析は、リモー トセンシング画像に扰いて領域分割と，その分類に用い られ，多くの成果を得ているが，近年では，さらに人間 の感覚之の関係む謂へらられている ${ }^{13)}$

分割された各領域加ら，濃度，色の平均值，分散な どの特徵量, 方向性, 踈密性, 直楾性などのテクスチャ 一特徵量, あるい恓，面皘，周囲長，形状の凸凸度，線 四形では，線の方向，分吱点，端点の位置，ループの存 在などの特徵量を抽出することができる。

\section{4. 染色欠点の検出}

計算機画像処理の䋐維工業への応用として，すでにい

表 1 微分オペレータと処理例

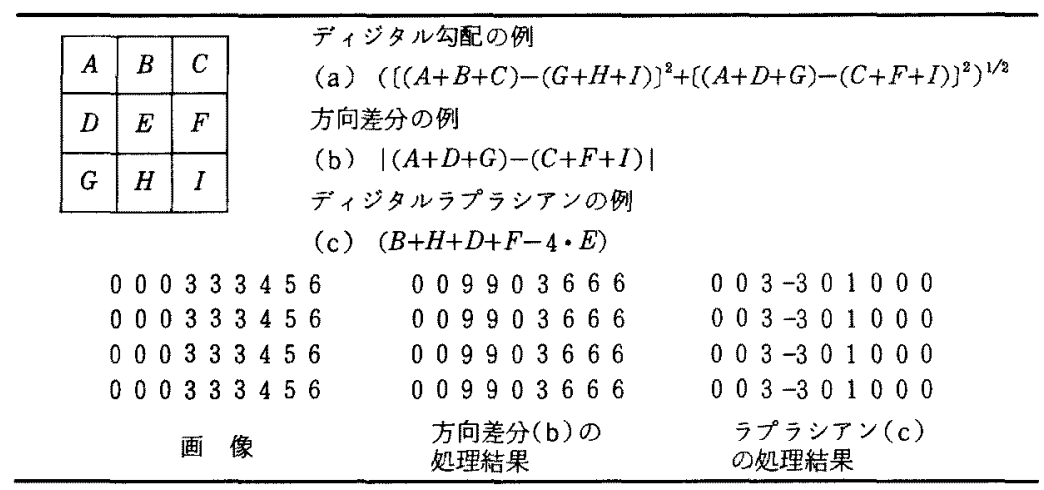



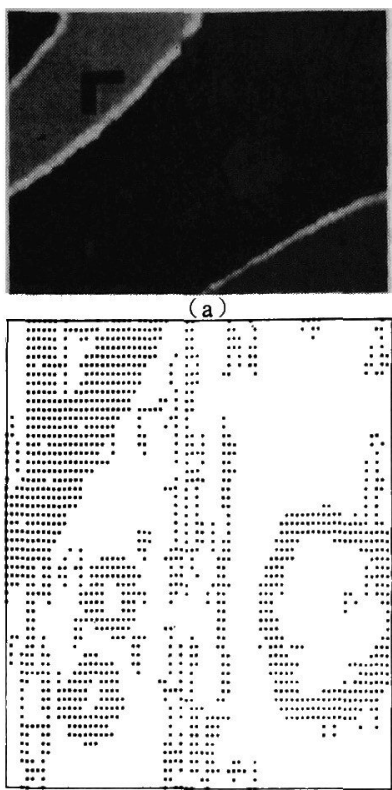

(b)

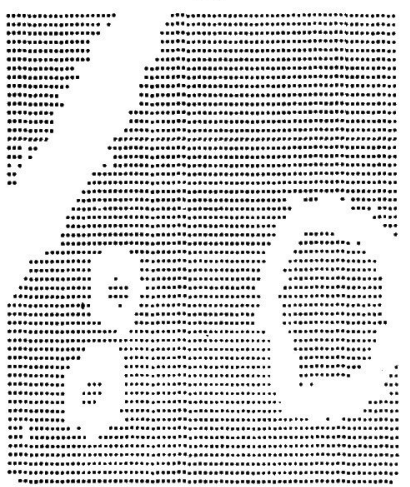

(c)

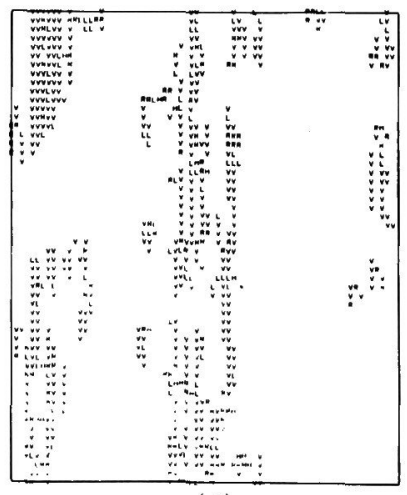

(d)

図 5 染色欠点の検出
くつかの基礎的研究が報告されている。文献 14)では， 二，三の自動検反システムが紹介され，文献 15)では， 種々の観測条件での織布欠点の検出可能性が論じられて (る。また，文献 16)，17），18）では，射影による織布 欠点検出法が提唱され，観測データ処理法の側から織布 欠点自動処理の可能性が示されている。さらに，染色欠 点の検出に関して筆者らによる一試みがあり，処理の概 要は次の通りである。

図 5 (a)は, 色柄を有する染色布であり中央及び左端 亿縦線状の染色欠点(色むら)がある。同図(b)は (a)を カラーテレビカメラで観測し A-D変換して得た縦 60 , 横 80 画素，濃度レベル 256 のディジタル濃淡画像を做 分処理し, 微分値がある閥值以上の領域を示したもので ある。ここでは，染色むらと柄エッジ(地と柄あるいは 柄と柄の境界)の両方が抽出されており，染色むらを区 別するためには，さらに処理が必要となる。一般に，染 色むらは地の色に対して濃度がわずかに異なる程度であ り色度変化はほとんどない。一方，柄エッジではその性 質上, 大きな色度变化が存在することから，色度変化量 を調へるととにより両者の識別が可能となる。色度変化 量はカラーテレビカメラから得られる 3 原色画像を基に, 各画素において近傍の画素との色度の違い，すなわち色 度べクトルのなす角の余弦として定量化できる。図 5 (c) は色度変化がある間値よりも小さい領域を示したもので あり，柄エッジのみが空白に表示されている。したがっ て染色欠点は同図 (b) と (c)の論理積により得られ，そ の結果を同図(d)に示す。

以上の処理の方法は，文献 19）に詳しく述べている。 また，無地の染色布を対象として，主に濃度解析的手法 により染色欠点を検出する一例は，文献 20$)$ に述べてい る。

欠点領域が検出されれば，欠点の大きさ (面積)，形状， 方向性, 欠点の分布, 頻度などの情報を得ることは容易 であり，乙れらの情報により染色欠点の発生原因を推定 することもできよう。

\section{5. むすび}

ここでは，計算機画像好理に関する基礎的な事項につ いて述へ，纎維工業への応用例として，色柄を有する染 色布の欠点の検出の方法を示した。

計算機画像処理の分野は，半導体技術の進歩に伴って 今後飛躍的な発展が期待でき, 高度の処理を安価に実現 させ得る可能性を持っている。

今後，てれらの技術が繊維工業の各分野で一層皘極的 に取り入れられて，品質，生産性などの向上に役立つて とを望むむのである。 
謝辞：文献調査比関し，御教示在いただいた福种大学 工学部織維工学科の辻本石男教授に感謝いたします。

\section{文献}

1）川西達也，西川 茂：“最近の自動紋紙第孔装置の 開発”，織維工学，Vol.27，No.1，1974

2）西川茂: “織物のコンピュータ柄出し”，瀻維工 学, Vol.29, No. 6, 1976

3）久世栄一：“最近のアメリカに戈㚈る検反，綎製の 自動化システムについて”，䋐維と工業，Vol.34， No. 1, 1978

4）坂井利之，金出武雄：“ディジタル画像情報の会話 形処理システム” 情報処理, Vol.15，No.12， 1974

5）伊藤貴康：“画像処理ソフトゥェア”，電子通信学 会誌, Vol. 59 , No. 11, 1976

6）杢村雄太郎，福島重広，相馬敬司：“小規模八ード ウェアで実現する会話形沈用画像処理システム”， 電子通信学会技術研究報告，PRL 78-84, 1979

7）山本真司：“投影加らの再生(CT)”，情報処理， Vol. 20, No.12, 1979

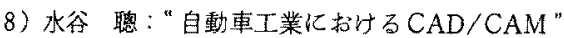
情報処理，Vol.21，No.2，1980

9) A. Rosenfeld, A.Kak (著)，長尾 真(訳) : "デ 1 ジタル画像処理" 近代科学社, 1978

10）榎本 肇：“画像の情報処理”, コロナ社, 1978

11）伊藤貴康，他：“画像処理つアームウェアを用いた 色彩図形解析システム”, 電子通信学会技術研究報 告, PRL 76-87, 1977
12）富田文明，白井良明，辻 三郎：“テクスチャ一の 解析”，情報処理，Vol.19，No. 2，1978

13）田村秀行，森俊二，山脇隆司：“テクスチャ一画 像の基礎的特徵の測定 (1) - 基礎的特徵之視賞心 理実験 - ", 電子道信学会技術研究報告, PRL 76 $-27,1976$

14）竹松 茂: “隼備・検反(総論)”繊維工学, Vol. 29, No. 6,1976

15）浩谷惇夫，相坂 登: “布欠点の検出可能性につい て”，瀻維工学，Vol.29，No. 9, 1976

16）舆水大和，青井清司: “䅧布欠点画像処理汇関する 基跣的考察”，炤和 52 年度電子通信学会総合全国 大会論文集， 1172

17）舆水大和，青井清司：“射影飞上る織布久点檢出の 一方法”，昭和 53 年度電子通信学会総合全国大会 論文集, 1203

18）舆水大和，青井清司：“計算機画像処理飞よる織布 欠点処理の試み”，画像コンファレンス 2-5, 昭和 53 年

19）谷口慶治，小川秀夫，酒并孝則：“染色の自動化任 関す石研究(計算機画像处理に上る染色欠点の検出) [その 2 ]”，福井大学工学部瀻維工業研究施設報告， Vol. 17, 1980

20）谷口慶治，小川秀夫，酒井孝則：“染色の自動化に 関する研究 (計算機画像処理に上万染色欠点の检出) 〔その 1)” 福井大学工学部瀻維工業研究施設報告, Vol. 16, 1978

21）今井 聖: “トランジスタ DA・AD変換器”, 産報 (昭和 55 年 3 月 15 日受理) 